\title{
PEARL MILLET SEED PELLETING ${ }^{1}$
}

\author{
FABRÍCIO BECKER PESKE², ANA DIONISIA L. C. NOVEMBRE ${ }^{3}$
}

\begin{abstract}
The pearl millet seed is small and its size varies, making sowing more difficult. The pelleting technique increases and homogenizes seed size, but it is essential to determine the physical and physiological characteristics of pelleted seeds. The physiological analysis consisted of: first germination count, final germination, speed emergence index, and seedling emergence. Physical analysis consisted of determining the 1000-seed weight, 1000-seed volume and fragmentation. The control treatment did not receive any coating, and the other 36 treatments combined four binders: bentonite, polyvinyl acetate (PVA), polyvinylpyrrolidone (PVP) and methyl cellulose (Methocel ${ }^{\circledR}$ ), and nine powder coating products: microcellulose, plaster, vermiculite, magnesium thermophosphate (Yoorin $\left.{ }^{\circledR}\right)$, phytic acid, dicalcium phosphate, super simple phosphate (SS), monoamonic phosphate (MAP) and reactive phosphate. Among the materials used to form the pearl millet pellet, the most efficient binders were the polyvinyl acetate and the methyl cellulose, and as coaters, the vermiculite and the microcellulose.
\end{abstract}

Index terms: coating, Pennisetum glaucum (L.) R. BR, binders.

\section{PELETIZAÇÃO DE SEMENTES DE MILHETO}

\begin{abstract}
RESUMO - As sementes de milheto são pequenas e têm tamanho variado, vindo a dificultar a semeadura. A técnica de peletização aumenta e uniformiza a forma das sementes. No entanto, é necessário determinar as características físicas e fisiológicas das sementes peletizadas. Logo, as análises fisiológicas consistiram do teste de germinação, primeira contagem de germinação, índice de velocidade de emergência e emergência final. As análises físicas consistiram do teste de peso de mil sementes, volume de mil sementes e fragmentação. A testemunha foi o tratamento de sementes sem peletização, os demais 36 tratamentos combinaram quatro adesivos: bentonita, acetato de polvinilina (PVA), polivinilpirrolidona (PVP) e metil celulose (Methocel®), e nove produtos de enchimento em pó: microcelulose, gesso, vermiculita, termofosfato magnesiano (Yoorin ${ }^{\circledR}$ ), fitina, fosfato bicálcico, fosfato super simples (SS), fosfato monoamônico (MAP) e fosfato natural reativo. Dentre os materiais testados para formar a pelota de semente de milheto nesta pesquisa, os adesivos mais eficientes foram o acetato de polvinilina e a metil celulose. Já os materiais de enchimento em pó mais eficientes foram a vermiculita e a microcelulose.
\end{abstract}

Termos para indexação: recobrimento, Pennisetum glaucum (L.) R. BR, adesivos.

${ }^{1}$ Submitted on 21/04/2010. Accepted for publication on 02/10/2010.

${ }^{2}$ MSc Eng. Agr., post-graduate Department of Plant Production, USP/ ESALQ, fpeske@yahoo.com.br.
${ }^{3}$ Eng. Agr., Dr., Professor Doctor, Department of Plant Production, USP/ ESALQ, Caixa p. 9, 13418 -900. Piracicaba, adlcnove@esalq.usp.br. 


\section{INTRODUCTION}

Pearl millet is cultivated in both summer and winter and is used for grazing or for forage, by cutting the plant and making hay. It can also serve for silage, grain production for human consumption and be cultivated to produce straw in a no-till system (Salton; Kichel, 1997).

Gardner e Vanderlip (1989) and Maiti et al. (1990) observed that the lack of uniformity in the development of the millet plant is a problem, which has its origin in the variation in seed size. This prejudices the formation of a suitable plant population for cultivation and an ideal inter-plant distance, and, consequently, potential crop productivity, since natural resources, such as water and sunlight may not be properly used.

Pelleting, which is the technique for coating seeds, is a potential alternative for improving sowing efficiency, since it allows the seeds not only to gain both weight and volume but also standardizes seed size in terms of length, width and thickness. Furthermore, the pellet's external surface is smooth and not deformed, facilitating its planting by seed drills (Silva, 1998).

However, pelleting is mainly used for seeds which have a high market value, such as tobacco, eucalyptus, some vegetables and ornamental plants, but is uncommon for smaller seeds, such as grasses, which have a lower market value,

The materials used for coating seeds are classified into two groups: binder materials and bulking or coating materials (Gimenez - Sampaio; Sampaio, 1994).

The binders that are commonly used to inoculate vegetable seeds usually originate from polymers and, therefore, have a high molecular weight; included among these are Gum Arabic, methyl cellulose, polyvinylpyrrolidone (PVP) and polyvinyl acetate (PVA). According to Silva \& Nakagawa (1998a), the "Cascorez Extra ${ }^{\circledR}$ " PVA adhesive was the one which showed the best physiological performance for coating cucumber, lettuce and tomato seeds.

Howieson et al. (1987) found that the use of PVP is appropriate for coating seeds that will be submitted to impact and abrasion during sowing or those which will be mixed with fertilizers.

The methyl celluloses, such as Methofas ${ }^{\circledR}$, Cellofas ${ }^{\circledR}$ and Methocel ${ }^{\circledR}$, are non-ionic cellulose ethers, soluble in water, which are recommended because they are semisynthetic polymers that are economic due to their low use concentrations (Scott, 1989).
Silva at al. (2002) also studied bentonite as a binder for pelleting lettuce seeds. Evaluating different combinations of bentonite and PVA, they found that bentonite aggregates the coating particles and that a $100 \%$ use of bentonite, after drying at $36{ }^{\circ} \mathrm{C}$, improved seed quality.

There has been a variety of promising products used for coating seeds, including microcrystalline cellulose (microcellulose), which is a thin, white, odorless, crystalline powder, originating from partial acid hydrolysis that causes depolymerization of the cellulose chains. These particles are not fibrous and they aggregate to form tablets that rapidly disintegrate in contact with water (Almeida, 2004).

However, other products are being tested as a coating for pelleting seeds, but their viability will depend on their compatibility with the binders and other materials on the seeds.

The objective of this study was to determine the physical characteristics of the pellet and the physiological quality of the seeds used in the pelleting of Pearl millet seeds submitted to different binders and coaters.

\section{MATERIAL AND METHODS}

The pelleting process was done at the IPEF, a research institute of the University of São Paulo (USP). All the physical and physiological analyses were made at the Seed Science Laboratory of ESALQ/USP in Piracicaba-SP.

The seeds used in this study came from a BRS 1501 seed lot, previously hand-classified using several sieves, and choosing those seeds which remained in the $3.5 \mathrm{~mm}$ oblong hole sieve.

The machine used in the pelleting process is composed of a convex stainless steel chamber, which has an adjustable and automated rotation speed. The coating product was added manually with the help of an ordinary sieve. The binders, diluted in water, were added with a plastic sprayer capable of spraying $10 \mathrm{~mL}$ of binder at every 40 sprays. The binders, in the form of a powder, were mixed to the products along with water sprays during the pelleting process.

The pelleting technique consisted of placing $15 \mathrm{~g}$ of seeds in the rotating chamber, followed by $5 \mathrm{~mL}$ of binder, intercalated with $3 \mathrm{~g}$ of coating, which were added until the pellets achieved the required diameter to be classified by a $4.5 \mathrm{~mm}$ round hole sieve. Those seeds that did not reach the minimum required size 
were returned to the machine to complete the pelleting process; the procedure was repeated until all the pellets reached the minimum established width of $4.5 \mathrm{~mm}$.

There were 37 treatments; the control seeds received no coating and the other 36 treatments combined four binders: bentonite, polyvinyl acetate (PVA), polyvinylpyrrolidone (PVP) and methyl cellulose (Methocel®) and nine coating products as powders: microcrystalline cellulose, plaster, vermiculite, magnesium thermophosphate (Yoorin $\AA$ ), phytic acid, dicalcium phosphate, super simple phosphate (SS), monoamonic phosphate (MAP) and reactive phosphate.

In order to give the pellet physical resistance to the individual coating compounds, $20 \%$ (vol./vol.) of microcrystalline cellulose (proportion 4:1) was added to each coating compound in each treatment and these treatments were then compared with those which did not have microcrystalline cellulose added (Table 1).

TABLE 1. Combination and proportion of adhesive and powder coating products used in the pearl millet (Cultivar BRS 1501) pelleting process.

\begin{tabular}{|c|c|c|c|c|c|c|c|c|}
\hline $\begin{array}{c}\text { Binders } \\
\text { Bentonite }\end{array}$ & \multicolumn{8}{|c|}{ Coating powders } \\
\hline $\begin{array}{c}\text { Bentonite } \\
\text { Methocel } \\
\text { PVA } \\
\text { PVP }\end{array}$ & Microcel. & $\begin{array}{l}\text { Magnes. } \\
\text { Thermoph. }\end{array}$ & $\begin{array}{l}\text { Bicalc. } \\
\text { Phosph. }\end{array}$ & $\begin{array}{l}\text { Phytic } \\
\text { acid }\end{array}$ & SS & MAP & Plaster & Vermiculite \\
\hline $\begin{array}{c}\text { Bentonite } \\
\text { Methocel } \\
\text { PVA } \\
\text { PVP }\end{array}$ & Microcel. & $\begin{array}{c}\text { Magnes. } \\
\text { Thermoph.+ } \\
\text { Microcel. } \\
(4: 1)\end{array}$ & $\begin{array}{c}\text { Bicalc. } \\
\text { Phosph.+ } \\
\text { Microcel. } \\
(4: 1)\end{array}$ & $\begin{array}{c}\text { Phytic } \\
\text { acid + } \\
\text { Microcel. } \\
(4: 1)\end{array}$ & $\begin{array}{c}\text { SS + } \\
\text { Microcel. } \\
(4: 1)\end{array}$ & $\begin{array}{c}\text { MAP + } \\
\text { Microcel. } \\
\quad(4: 1)\end{array}$ & $\begin{array}{c}\text { Plaster + } \\
\text { Microcel. } \\
\quad(4: 1)\end{array}$ & $\begin{array}{c}\text { Vermiculite } \\
+ \text { Microcel. } \\
\quad(4: 1)\end{array}$ \\
\hline
\end{tabular}

The treatments that did not receive the microcrystalline cellulose to the coating product were evaluated for fragmentation, which is a physical characteristic of the pellet. However, those treatments which had the microcrystalline cellulose added to the coating powder were evaluated for physical and physiological characteristics.

The binders were applied as follows: $80 \mathrm{~g}$ of bentonite were diluted in $1 \mathrm{~L}$ of water; PVA was diluted in water in the proportion of $20 \%$ (vol./vol.); methyl cellulose was mixed with the coating powder at a proportion of $10 \%$ (vol./vol.); and PVP was diluted in water at a proportion of $10 \%$ (vol./vol.).

After the pelleting process, the seeds were dried by artificial aeration at $30^{\circ} \mathrm{C}$ for 30 minutes. Random seed samples were collected to check the water content of most treatments with binder diluted in water and ensuring that the moisture content was not above $11 \%$.

The physical analysis consisted of determining the 1000 -seed weight, 1000-seed volume and fragmentation. The weight was determined according to the "Rules for
Testing Seeds" (Brasil, 1992), using 8 replications of 100 seeds. The 1000 -seed volume was obtained from the average value of 2 measurements of the volume occupied by an established mass of seeds dropped (free fall) into a graduated beaker.

The fragmentation test consisted of manually shaking a plastic bag with 50 seeds for one minute. Four replications of 50 seeds for each treatment were tested. The fragmentation was evaluated visually and the total number of cracked or broken pellets was counted with the help of a 10x hand lens. The results were expressed as the total number of fragmented seeds (Mendonça et al., 2007).

The physiological analysis consisted of: first germination count (FGC), final germination at day 7 $(\mathrm{G})$, seedling speed emergence index (SEI), and final emergence at day 7 (FE) (Bahry et al., 2007).

The experiment used a completely randomized design, with four replications. The experimental design was a factorial of $4 \times 9$ (binders $\mathrm{x}$ coatings) plus the control, with a total of 148 experimental units. Statistical 
analysis included analysis of variance and a comparison of means using the Dunnett and Tukey test $(\mathrm{p} \leq 0.05)$.

\section{RESULTS AND DISCUSSION}

The fragmentation analysis of the pelleted material (Table 2) showed that the microcrystalline cellulose significantly affected the integrity of the pelleted seeds, by increasing pellet resistance in most treatments.

Reactive phosphate, phytic acid and plaster were the coating products which fragmented most when associated with bentonite and PVP without the addition of microcrystalline cellulose. However, the number of fragmented seeds decreased when microcrystalline cellulose and PVP were added to the other products.

TABLE 2. Mean percentage of the pearl millet seed pelleting combinations (cultivar BRS 1501) submitted to the fragmentation test.

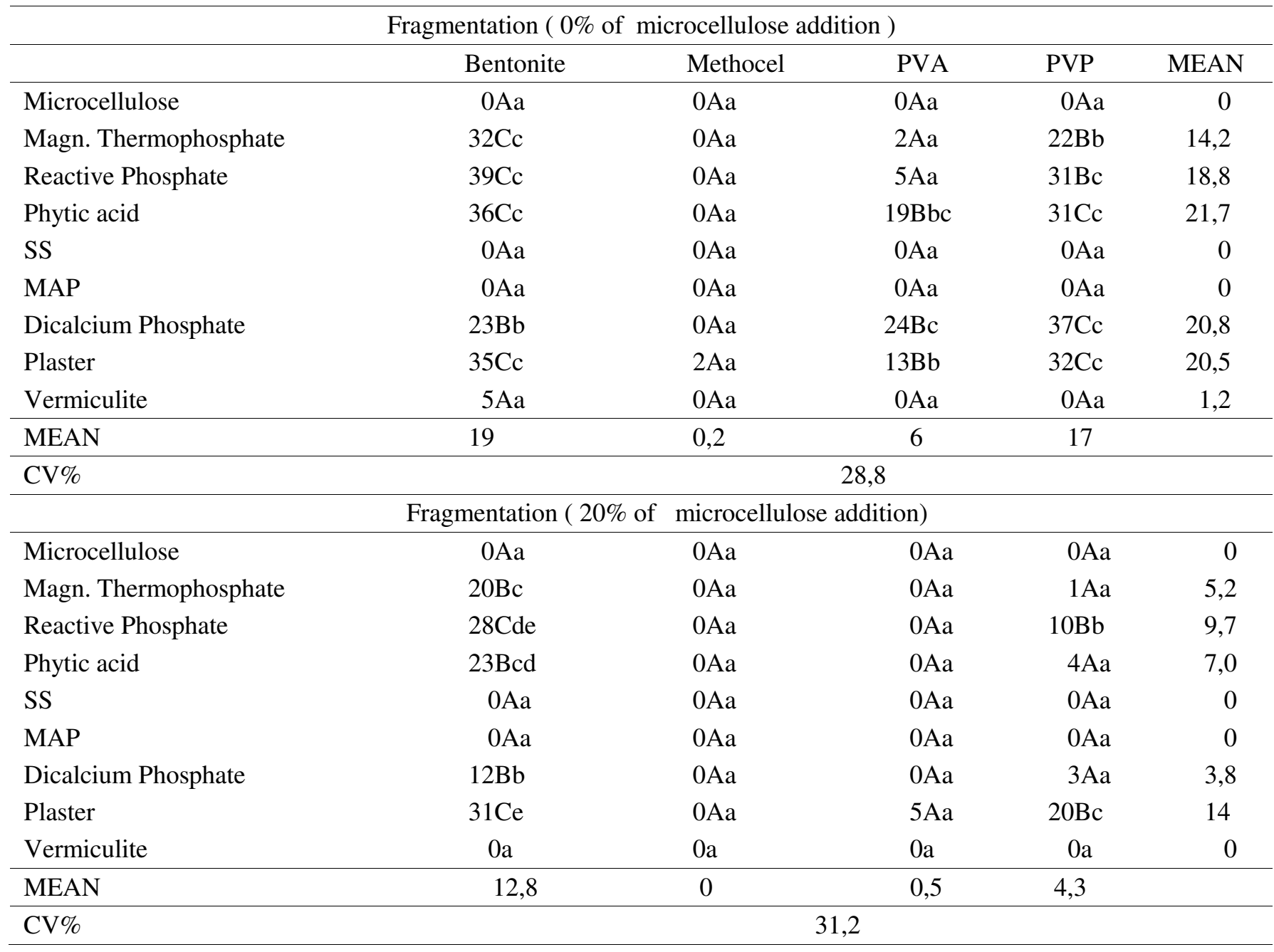

* The means within each column and followed by the same letter, as well as the means within each line and followed by the same capital letter do not differ among themselves, according to the Tukey statistical test, on a 5\% level of probability

Among the seeds pelleted with $20 \%$ microcrystalline cellulose added to the coating powder, the highest fragmentation level was observed in the mixture of plaster with bentonite, which was the binder that gave the lowest resistance to the pellet, followed by PVP. On the other hand, methyl cellulose and PVA were the most efficient binders for maintaining the integrity of the pearl millet seed pellets.

According to Silva and Nakagawa (1998a), pellet 
consistency is established by the resistance of the bind between the particles of the binder and the coating powder. Therefore, the higher the proportion of the binder, or the larger the surface of contact, considering both the size and the porosity of the particles of the product used as coating, the higher is the binding capacity of the pellet structures.

Considering the information above, the coating products used in this study that showed significantly greater pellet integrity, were microcellulose, super simple phosphate, monoamonic phosphate and vermiculite.
The results of this study for the combination of vermiculite with PVA, for pellet integrity, were similar to those reported by Mendonça et al. (2007), who demonstrated the superiority of this treatment for pellet integrity compared to the other treatments.

Table 3 shows that there was no significant difference between the treatments for 1000-seed weight compared to the control. However, the 1000 -seed volume was significantly higher for all the treatments compared to the control

TABLE 3. Analysis of variance results for the 1000 seed weight, 1000 seed volume, germination at 7 days (G), first germination count (FGC), seedling speed emergence index (SEI) and final emergence count (FE) of the pearl millet seeds cultivar BRS1501, which were pelleted with combinations of binders and powder coating materials containing $20 \%$ of microcellulose, compared to the non-pelleted seeds.

\begin{tabular}{|c|c|c|c|c|c|c|c|c|}
\hline $\begin{array}{l}\text { Treatment } \mathrm{x} \\
\text { Check }\end{array}$ & Coating powder & Adhesive & $\begin{array}{c}\text { 1000-seed } \\
\text { weight }\end{array}$ & 1000-seed vol. & FGC & $\mathrm{G}$ & SEI & $\mathrm{FE}$ \\
\hline 1 & Microcellulose & Bentonite & ns & + & $\mathrm{ns}$ & ns & ns & ns \\
\hline 2 & Microcellulose & Methocel & $\mathrm{ns}$ & + & $\mathrm{ns}$ & $\mathrm{ns}$ & $\mathrm{ns}$ & ns \\
\hline 3 & Microcellulose & PVA & $\mathrm{ns}$ & + & ns & ns & $\mathrm{ns}$ & ns \\
\hline 4 & Microcellulose & PVP & $\mathrm{ns}$ & + & ns & ns & ns & ns \\
\hline 5 & Magnesium Thermo & Bentonite & $\mathrm{ns}$ & + & - & - & - & - \\
\hline 6 & Yoorin & Methocel & ns & + & $\mathrm{ns}$ & $\mathrm{ns}$ & ns & ns \\
\hline 7 & Yoorin & PVA & $\mathrm{ns}$ & + & $\mathrm{ns}$ & $\mathrm{ns}$ & ns & ns \\
\hline 8 & Yoorin & PVP & ns & + & $\mathrm{ns}$ & ns & ns & ns \\
\hline 9 & Reactive Phosphate & Bentonite & $\mathrm{ns}$ & + & - & - & - & - \\
\hline 10 & Reactive Phosphate & Methocel & $\mathrm{ns}$ & + & - & - & - & - \\
\hline 11 & Reactive Phosphate & PVA & $\mathrm{ns}$ & + & - & - & - & - \\
\hline 12 & Reactive Phosphate & PVP & $\mathrm{ns}$ & + & - & - & - & - \\
\hline 13 & Phytic acid & Bentonite & $\mathrm{ns}$ & + & $\mathrm{ns}$ & ns & ns & ns \\
\hline 14 & Phytic acid & Methocel & ns & + & ns & ns & ns & ns \\
\hline 15 & Phytic acid & PVA & ns & + & ns & ns & ns & ns \\
\hline 16 & Phytic acid & PVP & $\mathrm{ns}$ & + & $\mathrm{ns}$ & $\mathrm{ns}$ & $\mathrm{ns}$ & ns \\
\hline 17 & Dicalcium Phospate & Bentonite & $\mathrm{ns}$ & + & - & - & - & - \\
\hline 18 & Dicalcium Phospate & Methocel & $\mathrm{ns}$ & + & - & - & - & - \\
\hline 19 & Dicalcium Phospate & PVA & ns & + & ns & ns & ns & ns \\
\hline 20 & Dicalcium Phospate & PVP & ns & + & ns & ns & ns & ns \\
\hline 21 & SS & Bentonite & ns & + & - & - & - & - \\
\hline 22 & SS & Methocel & ns & + & - & - & - & - \\
\hline 23 & SS & PVA & $\mathrm{ns}$ & + & - & - & - & - \\
\hline 24 & SS & PVP & $\mathrm{ns}$ & + & - & - & - & - \\
\hline 25 & MAP & Bentonite & ns & + & - & - & - & - \\
\hline 26 & MAP & Methocel & ns & + & - & - & - & - \\
\hline
\end{tabular}

Continua... 
Continuação...

\begin{tabular}{cllcccccc}
\hline $\begin{array}{c}\text { Treatment } \\
\text { Check }\end{array}$ & Coating powder & Adhesive & $\begin{array}{c}\text { 1000-seed } \\
\text { weight }\end{array}$ & 1000-seed vol. & FGC & G & SEI & FE \\
\hline 27 & MAP & PVA & ns & + & - & - & - & - \\
28 & MAP & PVP & ns & + & - & - & - & - \\
29 & Plaster & Bentonite & $\mathrm{ns}$ & + & $\mathrm{ns}$ & $\mathrm{ns}$ & $\mathrm{ns}$ & $\mathrm{ns}$ \\
30 & Plaster & Methocel & $\mathrm{ns}$ & + & $\mathrm{ns}$ & $\mathrm{ns}$ & $\mathrm{ns}$ & $\mathrm{ns}$ \\
31 & Plaster & PVA & $\mathrm{ns}$ & + & $\mathrm{ns}$ & $\mathrm{ns}$ & $\mathrm{ns}$ & $\mathrm{ns}$ \\
32 & Plaster & PVP & $\mathrm{ns}$ & + & $\mathrm{ns}$ & $\mathrm{ns}$ & $\mathrm{ns}$ & $\mathrm{ns}$ \\
33 & Vermiculite & Bentonite & $\mathrm{ns}$ & + & $\mathrm{ns}$ & $\mathrm{ns}$ & $\mathrm{ns}$ & $\mathrm{ns}$ \\
34 & Vermiculite & Methocel & $\mathrm{ns}$ & + & $\mathrm{ns}$ & $\mathrm{ns}$ & $\mathrm{ns}$ & $\mathrm{ns}$ \\
35 & Vermiculite & PVA & $\mathrm{ns}$ & + & $\mathrm{ns}$ & $\mathrm{ns}$ & $\mathrm{ns}$ & $\mathrm{ns}$ \\
36 & Vermiculite & PVP & $\mathrm{ns}$ & + & $\mathrm{ns}$ & $\mathrm{ns}$ & $\mathrm{ns}$ & $\mathrm{ns}$ \\
\hline
\end{tabular}

+ Significant and superior to the check, by the Dunnett statistical test, on a $5 \%$ level of probability;

- Significant and inferior to the check, by the Dunnett statistical test, on a 5\% level of probability;

ns non-significant, by the Dunnett statistical test, on a $5 \%$ level of probability;

The physiological analysis showed that some treatments were significantly inferior to the control, including those that had the following coating products: the reactive phosphate, the super simple phosphate, the monoamonic phosphate, dicalcium phosphate (with bentonite and methyl cellulose) and magnesium thermophosphate associated with bentonite.

These physiological results support the conclusions reported by other authors with other species. When working with tomato seeds, Oliveira et al. (2003) concluded that seeds pelleted with combinations of microcellulose, sand and/or calcareous rock had a lower germination speed than the non-pelleted seeds (control).

\section{Physical Analysis}

With regard to the 1000 -seed weight, the weight increase of the pelleted seeds varied among the powder products and, at a lesser degree among the binders.

Table 4 shows that the super simple phosphate, followed by magnesium thermophosphate, dicalcium phosphate and monoamonic phosphate, were the coating materials which gave a higher increase in seed weight. The degree of the seed weight increase is evident when comparing the mean value of the super simple phosphate, which provided an increment of $268 \%$ when compared to the mean seed weight vale of the vermiculite.

PVA and methyl cellulose were the binders that increased the 1000-seed weight the most and also aggregated the pellet with the lowest fragmentation index when associated with monoamonic phosphate, super simple phosphate, dicalcium phosphate, phytic acid and magnesium thermophosphate. Bentonite was the least efficient in increasing the 1000 -seed weight.

Super simple phosphate, monoamonic phosphate and dicalcium phosphate were the materials that increased volume the most. However, vermiculite was the pelleted material that showed the lowest volume increase, although some authors have emphasized the efficiency of vermiculite as a coating material for pelleting seeds. Evaluating the changes in the physical conditions of carrot seeds that were pelleted in a prototype pelleting machine, Medeiros et al. (2004) used different combinations of vermiculite with polyvinyl acetate (PVA) and obtained significant results for the 1000 -seed weight and final machine production.

The PVA and the methyl cellulose were the binders that increased the 1000-seed weight and 1000-seed volume the most.

\section{Physiological Analysis}

Tables 5 and 6 showed that the use of monoamonic phosphate and super simple phosphate damaged the pearl millet seeds, as they caused a reduction in both seed germination and seedling emergence. Similar results were obtained by Soratto et al. (2003), who observed a harmful effect on germination and vigor for the period 
during which the seeds remained mixed with phosphate fertilizers. Phosphate rock processing using sulphuric (SSP) and phosphoric (TSP) acids leaves residues which adversely affect seed germination and vigor when mixed with the fertilizers, and this effect increases with prolonged contact.

TABLE 4. Mean percentage of the pearl millet seed pelleting combinations (cultivar BRS 1501) submitted to the 1000-seed weight and volume tests.

\begin{tabular}{|c|c|c|c|c|c|}
\hline \multicolumn{6}{|c|}{ 1000-seed weight $(\mathrm{g})$} \\
\hline & Bentonite & Methocel & PVA & PVP & MEAN \\
\hline Microcellulose & 19,3Acd & 18,7Ade & 19Ad & 16,6 Aef & 18,4 \\
\hline Magn. Thermophosphate & $23,1 \mathrm{Cbc}$ & 36Bab & $40 \mathrm{Aa}$ & $22,2 \mathrm{Ccd}$ & 30,3 \\
\hline Reactive Phosphate & $11,4 \mathrm{Df}$ & $22,3 \mathrm{Bcd}$ & $26,6 \mathrm{Ac}$ & $17,8 \mathrm{Cdef}$ & 19,5 \\
\hline Phytic acid & 16,8Ade & $17,2 \mathrm{Ae}$ & $18,7 \mathrm{Ad}$ & 16,4 Aef & 17,3 \\
\hline SS & $35,3 \mathrm{Ba}$ & $39,1 \mathrm{ABa}$ & $42,3 \mathrm{Aa}$ & $38,8 \mathrm{ABa}$ & 38,9 \\
\hline MAP & $23,4 \mathrm{Abc}$ & $26,4 \mathrm{Ac}$ & $26,7 \mathrm{Ac}$ & $23,8 \mathrm{Ac}$ & 25,1 \\
\hline Dicalcium Phosphate & $26,6 \mathrm{Bb}$ & $31,5 \mathrm{Ab}$ & $32,7 \mathrm{Ab}$ & $28,8 \mathrm{ABb}$ & 25,9 \\
\hline Plaster & $16,3 \mathrm{Bde}$ & 17,6ABde & $18,8 \mathrm{ABd}$ & 20,4Acde & 18,3 \\
\hline Vermiculite & 12,5 Aef & $15,5 \mathrm{Ae}$ & $15,2 \mathrm{Ad}$ & $14,7 \mathrm{Af}$ & 14,5 \\
\hline MEAN & 20,5 & 24,9 & 26,7 & 22,2 & \\
\hline Check & & & 9,6 & & \\
\hline CV\% & & & 8,9 & & \\
\hline \multicolumn{6}{|c|}{ 1000-seed volume $(\mathrm{ml})$} \\
\hline Microcellulose & $34,4 \mathrm{Abc}$ & $31,2 \mathrm{ABb}$ & $33,2 \mathrm{Ad}$ & $27,3 \mathrm{Bcd}$ & 31,5 \\
\hline Magn. Thermophosphate & $27,1 \mathrm{Cde}$ & $37,8 \mathrm{Bb}$ & $45,6 \mathrm{Abc}$ & $25,7 \mathrm{Ccd}$ & 34 \\
\hline Reactive Phosphate & $21,2 \mathrm{Ce}$ & $37 \mathrm{Ab}$ & $41,2 \mathrm{Ac}$ & $30,5 \mathrm{Bbc}$ & 32,5 \\
\hline Phytic acid & 24,1Ade & $23,8 \mathrm{Ac}$ & 25,6Aef & $23,3 \mathrm{Ad}$ & 24,2 \\
\hline SS & $42,9 \mathrm{Ba}$ & $45,7 \mathrm{Ba}$ & $55,2 \mathrm{Aa}$ & $48,5 \mathrm{Ba}$ & 48,1 \\
\hline MAP & 40,8Aab & $45,6 \mathrm{Aa}$ & $45,5 \mathrm{Abc}$ & $43,8 \mathrm{Aa}$ & 43,9 \\
\hline Dicalcium Phosphate & $42,3 \mathrm{Ba}$ & $48 \mathrm{ABa}$ & 49,2Aab & $42,6 \mathrm{Ba}$ & 45,5 \\
\hline Plaster & 30,1 Acd & $32,8 \mathrm{Ab}$ & 32,2Ade & $35,3 \mathrm{Ab}$ & 32,6 \\
\hline Vermiculite & $20,6 \mathrm{Ae}$ & $23,6 \mathrm{Ac}$ & $24,5 \mathrm{Af}$ & $23,3 \mathrm{Ad}$ & 23 \\
\hline MEAN & 31,5 & 36,2 & 39,1 & 33,4 & \\
\hline Check & & & 12,8 & & \\
\hline $\mathrm{CV} \%$ & & & 8,9 & & \\
\hline
\end{tabular}

* The means within each column and followed by the same letter, as well as the means within each line and followed by the same capital letter do not differ among themselves, according to the Tukey statistical test, on a $5 \%$ level of probability

Phytic acid favored the germination of the pearl millet seeds but the other products gave results which were inferior to the ones shown by the control and by the phytic acid (Table 5). There was no significant difference in the germination of the seeds for the binders.

As observed in Table 6, the results of the seedling speed emergence index and the seedling final emergence demonstrated a significant difference between bentonite and the other binders. However, the PVA binder, "Cascorez Extra ${ }^{\circledR}$ ”, was toxic to the emerged pearl millet seedling, causing leaf chlorosis for up to 21 days after seedling emergence but it did not influence the SEI average values 
and final seedling emergence. Similar results were observed by Silva \& Nakagawa (1998a), when they observed that a binder based on polyvinyl acetate (PVA), "Grundi
Extra®», was toxic to cucumber and tomato seeds for the final germination tests, germination speed, final emergence and seedling speed of emergence.

TABLE 5. Mean percentage of the pearl millet seed pelleting combinations (cultivar BRS 1501) submitted to the germination at 7 days (G) and first germination count (FGC), tests.

\begin{tabular}{|c|c|c|c|c|c|}
\hline \multicolumn{6}{|c|}{ First germinating counting ( $\%$ ) } \\
\hline & Bentonite & Methocel & PVA & PVP & MEAN \\
\hline Microcellulose & $69.5 \mathrm{Ab}$ & $66.5 \mathrm{Ab}$ & $70 \mathrm{Aa}$ & $73 \mathrm{Aa}$ & 69.7 \\
\hline Magn. Thermophosphate & $69 \mathrm{Ab}$ & 76Aab & $71 \mathrm{Aa}$ & $71.5 \mathrm{Aa}$ & 71.8 \\
\hline Reactive Phosphate & $64 \mathrm{Ab}$ & 70Aab & 66Aa & 71Aa & 67.7 \\
\hline Phytic acid & 81Aa & $78 \mathrm{ABa}$ & $70.5 \mathrm{Ba}$ & $73.5 \mathrm{ABa}$ & 75.7 \\
\hline SS & OAc & $0 \mathrm{Ac}$ & $0 \mathrm{Ab}$ & $0 \mathrm{Ab}$ & 0 \\
\hline MAP & $0 \mathrm{Ac}$ & $0 \mathrm{Ac}$ & $0 \mathrm{Ab}$ & $0 \mathrm{Ab}$ & 0 \\
\hline Dicalcium Phosphate & $66.5 \mathrm{Ab}$ & 70Aab & $72.5 \mathrm{Aa}$ & $73.5 \mathrm{Aa}$ & 70.6 \\
\hline Plaster & $69.5 \mathrm{Ab}$ & $66.5 \mathrm{Ab}$ & $68.5 \mathrm{Aa}$ & $69.5 \mathrm{Aa}$ & 68.5 \\
\hline Vermiculite & $69 \mathrm{Ab}$ & 69Aab & 69Aa & $68.5 \mathrm{Aa}$ & 68.8 \\
\hline MEAN & 54.2 & 55.1 & 54.1 & 55.6 & \\
\hline Check & & & 76.5 & & \\
\hline $\mathrm{CV} \%$ & & & 8.7 & & \\
\hline \multicolumn{6}{|c|}{ Germination at 7 days ( $\%$ ) } \\
\hline Microcellulose & $72.5 \mathrm{Aab}$ & $70 \mathrm{Aa}$ & $71.5 \mathrm{Aa}$ & $76 \mathrm{Aa}$ & 72.5 \\
\hline Magn. Thermophosphate & $72.5 \mathrm{Aab}$ & $77.5 \mathrm{Aa}$ & $77.5 \mathrm{Aa}$ & $74.5 \mathrm{Aa}$ & 75.5 \\
\hline Reactive Phosphate & $70.5 \mathrm{Ab}$ & $72 \mathrm{Aa}$ & $71 \mathrm{Aa}$ & $75.5 \mathrm{Aa}$ & 72.2 \\
\hline Phytic acid & $82.5 \mathrm{Aa}$ & 80Aa & $75.5 \mathrm{Aa}$ & $75 \mathrm{Aa}$ & 78.2 \\
\hline SS & $0 \mathrm{Ac}$ & $0 \mathrm{Ab}$ & $0 \mathrm{Ab}$ & $0 \mathrm{Ab}$ & 0 \\
\hline MAP & $0 \mathrm{Ac}$ & $0 \mathrm{Ab}$ & $0 \mathrm{Ab}$ & $0 \mathrm{Ab}$ & 0 \\
\hline Dicalcium Phosphate & $66.5 \mathrm{Bb}$ & $72 \mathrm{ABa}$ & $75 \mathrm{Aa}$ & 78Aa & 72.8 \\
\hline Plaster & $72.5 \mathrm{Aab}$ & $70 \mathrm{Aa}$ & $72 \mathrm{Aa}$ & $72.5 \mathrm{Aa}$ & 71.7 \\
\hline Vermiculite & 74Aab & $76 \mathrm{Aa}$ & $73.5 \mathrm{Aa}$ & 74Aa & 74.3 \\
\hline MEAN & 56.7 & 57.5 & 57.3 & 58.3 & \\
\hline Check & & & 78 & & \\
\hline CV\% & & & 8 & & \\
\hline
\end{tabular}

* The means within each column and followed by the same letter, as well as the means within each line and followed by the same capital letter do not differ among themselves, according to the Tukey statistical test, on a $5 \%$ level of probability 
TABLE 6. Mean percentage of the pearl millet seed pelleting combinations (cultivar BRS 1501) submitted to the seedling speed emergence index (SEI) and final emergence count (FE) tests.

\begin{tabular}{|c|c|c|c|c|c|}
\hline & \multicolumn{4}{|c|}{ seedling speed emergence index $(\%)$} & \multirow[b]{2}{*}{ MEAN } \\
\hline & Bentonite & Methocel & PVA & PVP & \\
\hline Microcellulose & $13.4 \mathrm{Bab}$ & 14.1Bbcd & $14 \mathrm{Bb}$ & $17.1 \mathrm{Aa}$ & 14.7 \\
\hline Magn. Thermophosphate & $12.2 \mathrm{Ab}$ & 13.2Abcd & $13.5 \mathrm{Ab}$ & $14.5 \mathrm{Aab}$ & 13.3 \\
\hline Reactive Phosphate & $11.9 \mathrm{ABb}$ & $12.1 \mathrm{ABd}$ & $9.9 \mathrm{Bc}$ & $12.6 \mathrm{Ab}$ & 11.6 \\
\hline Phytic acid & $13.5 \mathrm{Bab}$ & $17.1 \mathrm{Aa}$ & $15.2 \mathrm{ABab}$ & 14.6Bab & 15.1 \\
\hline SS & $0 \mathrm{Ac}$ & OAe & OAd & $0 \mathrm{Ac}$ & 0 \\
\hline MAP & $0 \mathrm{Ac}$ & $0 \mathrm{Ae}$ & $0 \mathrm{Ad}$ & $0 \mathrm{Ac}$ & 0 \\
\hline Dicalcium Phosphate & $11.9 \mathrm{Bb}$ & $12.5 \mathrm{Bcd}$ & 15.7Aab & 15.4Aab & 13.9 \\
\hline Plaster & 14.3Aab & 15.3Aabc & 15.7Aab & 14.6Aab & 15 \\
\hline Vermiculite & $15.2 \mathrm{Aa}$ & $15.5 \mathrm{Aab}$ & 16.9Aa & $15.7 \mathrm{Aa}$ & 15.8 \\
\hline MEAN & 10.2 & 11.1 & 11.2 & 11.6 & \\
\hline Check & \multicolumn{5}{|c|}{15.5} \\
\hline $\mathrm{CV} \%$ & \multicolumn{5}{|c|}{11.6} \\
\hline \multicolumn{6}{|c|}{ final emergence counting at 7 days( $\%$ ) } \\
\hline Microcellulose & $63 \mathrm{Ba}$ & $65.5 \mathrm{ABabc}$ & $67.5 \mathrm{ABa}$ & 75.2Aa & 67.8 \\
\hline Magn. Thermophosphate & $57.5 \mathrm{Ba}$ & $66.5 \mathrm{ABabc}$ & $68 \mathrm{Aa}$ & $68 \mathrm{Aab}$ & 65 \\
\hline Reactive Phosphate & $55.5 \mathrm{ABa}$ & $57 \mathrm{Ac}$ & $47 \mathrm{Bb}$ & $58.5 \mathrm{Ab}$ & 54.5 \\
\hline Phytic acid & $62 \mathrm{Ba}$ & 76Aa & $69.5 \mathrm{ABa}$ & $67.5 \mathrm{ABab}$ & 68.7 \\
\hline SS & $0 \mathrm{Ab}$ & 0Ad & OAc & OAc & 0 \\
\hline MAP & $0 \mathrm{Ab}$ & $0 A d$ & $0 \mathrm{Ac}$ & $0 \mathrm{Ac}$ & 0 \\
\hline Dicalcium Phosphate & $56 \mathrm{Ba}$ & $58 \mathrm{Bbc}$ & $76.5 \mathrm{Aa}$ & $69.5 \mathrm{Aab}$ & 65 \\
\hline Plaster & $66.5 \mathrm{Aa}$ & $72 \mathrm{Aa}$ & $71.5 \mathrm{Aa}$ & 68Aab & 69.5 \\
\hline Vermiculite & $67 \mathrm{Aa}$ & $69.5 \mathrm{Aab}$ & $74.5 \mathrm{Aa}$ & $70.5 \mathrm{Aab}$ & 70.3 \\
\hline MEAN & 47.5 & 51.6 & 52.7 & 53 & \\
\hline Check & \multicolumn{5}{|c|}{72} \\
\hline CV\% & \multicolumn{5}{|c|}{10,5} \\
\hline
\end{tabular}

* The means within each column and followed by the same letter, as well as the means within each line and followed by the same capital letter do not differ among themselves, according to the Tukey statistical test, on a $5 \%$ level of probability

Among the coaters, the results were homogeneous for both the seedling speed emergence index and seedling final emergence evaluations. Although there are exceptions, such as the reactive phosphate, which was significantly inferior when compared to the others, and also both the super simple phosphate and monoamonic phosphate, that inhibited seed germination.

As the percentage of germination and emergence were similar to the ones verified with the check (unpelleted seeds), the results obtained with vermiculite were similar to the ones obtained by Medeiros et al. (2006) for carrot seeds. They evaluated the physiological performance of pelleted carrot seeds using vermiculite as the coating material and polyvinyl acetate (PVA) as binder and found that using vermiculite as a coater, in a 3:1 proportion (vermiculite:seed) associated to the PVA as binder and the fungicides thiram + carbendazim, did not affect germination. 
The physiological results obtained with the treatment that used magnesium thermophosphate on pearl millet seeds, did not differ significantly from the control and the other treatments, and contrast with the results obtained for other species. According to Silva and Nakagawa (1998b), the pelleting of lettuce seeds with thermophosphate (Yoorin ${ }^{\circledR}$ ) adversely affected seedling emergence, germination and the seedling speed emergence index.

However, Magalhães et al. (1994), evaluating the effect of different fertilizer coatings on sorghum seeds, observed that the treatment with magnesium thermophosphate (Yoorin ${ }^{\circledR}$ ) gave the best results for all the physiological analyses.

\section{CONCLUSIONS}

Among the materials used to form the pearl millet pellet, the most efficient coaters are the vermiculite and the microcrystalline cellulose.

The coating materials, microcrystalline cellulose, phytic acid, plaster, vermiculite and magnesium thermophsphate do not cause a significant difference in the physiological performance of the seeds. On the other hand, super simple phosphate (SS) and monoamonic phosphate cause significant damage to seed physiological performance.

The most efficient binders, both physically and physiologically, are the polyvinyl acetate (PVA) and the methyl cellulose, called "Methocel®”.

\section{ACKNOWLEDGMENTS}

The authors thank the CNPq for a scholarship and the Colorcon and Fertilizantes Mitsui companies for supplying the Methocel ${ }^{\circledR}$ binder and Yoorin ${ }^{\circledR}$ powder product, respectively.

The IPEF Institute supplied all the infrastructure and equipment for the seed pelleting process.

\section{REFERENCES}

ALMEIDA, N.O. Implantação de matas ciliares por plantio direto utilizando-se sementes peletizadas. 269p. Dissertação - UFLA, Lavras-MG, 2004.

BAHRY, C.A.; CASAROLI, D.; MUNIZ, M.F.B.; GARCIA, D.C.; MENEZES, N.L.; ZANATA, Z.C. Avaliação da qualidade fisiológica e sanitária de sementes de milheto. Revista da FZVA, v.14, n.1, p.25-35, 2007. http://revistaseletronicas.pucrs.br/ojs/index.php/fzva/ article/viewFile/2476/1935

BRASIL. Ministério da Agricultura e Reforma Agrária. Secretaria Nacional de Defesa Agropecuária. Departamento Nacional de Produção Vegetal. Coordenação de Laboratório Vegetal. Regras para Análise de Sementes. Brasília, DF, 1992. 365p.

GARDNER, J.C.; VANDERLIP, R.L. Seed size and density effects on field performance of pearl millet. Transactions of the Kansas Academy of Science, v.92 n.1-2, p.49-59, 1989. http://www.jstor.org/stable/3628189? cookieSet $=1$

GIMÉNEZ-SAMPAIO, T.; SAMPAIO, N.V.Recobrimento de sementes. Informativo ABRATES, v.4, n.3, p.20-52, 1994.

HOWIESON, J.G.; EWING, M.A.; THORN, C.W. Inoculation and lime pelleting of medic seed. Western Australian Department of Agriculture, 1987. 65p.

HOWESON, J.G; EWING, M.A; THORN, C.W. Inoculation and line of medie seed. Western Australian, 1987. 65p.

MAGALHÃES, P.C.; FERREIRA, D.M.N.; VASCONCELOS, C.A.; AZEVEDO, J.T.; BORBA, C.S. Efeito da peletização na germinação e desenvolvimento de cultivares de sorgo. Revista Brasileira de Sementes, v.16 n.1, p.20-25, 1994. http://www.abrates.org.br/revista/ artigos/1994/v16n1/artigo04.pdf

MAITI, R.K.; RAJU, P.S.; BIDINGER, F.R. Seedling vigor in pearl millet. I. Role of seed size. Turrialba (IICA), v.40, n.3, p.353-355, 1990. http://www.jstor.org/stable/3628189

MEDEIROS, E.M.; BAUDET, L.; PERES, W.B.; EICHOLZ, E.D. Modificações na condição física das sementes de cenoura em equipamento de recobrimento. Revista Brasileira de Sementes, v.26, n.2, p.70-75, 2004. http://www.scielo.br/scielo.php?script=sci arttext\&pid=S0101-31222004000200010

MEDEIROS, E.M.; BAUDET, L.; PERES, W.B.; PESKE, F.B. Recobrimento de sementes de cenoura com aglomerante em diversas proporções e fungicida. Revista Brasileira de Sementes, v.28, n.3, p.94-100, 2006. http:// www.scielo.br/pdf/rbs/v28n3/14.pdf

MENDONÇA, E.A.F.; CARVALHO, N.M.; RAMOS, N.P. Revestimento de sementes de milho superdoce (sh2). Revista Brasileira de Sementes, v.29, n.2, p.6879, 2007. http://www.scielo.br/scielo.php?pid=S010131222007000200010\&script $=$ sci_arttext 
OLIVEIRA, J.A.; PEREIRA, C.A.; GUIMARÃES, R.M.; VIEIRA, A.R.; SILVA, J.B.C. Efeito de diferentes materiais de peletização na deterioração de sementes de tomate durante o armazenamento. Revista Brasileira de Sementes, v.25, n.2, p.20-27, 2003. http://www.scielo.br/ pdf/rbs/v25n2/19645.pdf

SALTON, J.C.; KICHEL, A.N. Milheto: alternativa para cobertura do solo e alimentação animal. In: Informações Agronômicas, Piracicaba, 1997, p.8-9.

SCOTT, J.M. Seed coatings and treatments and their effects on plant establishment. In: Advances in Agronomy, San Diego: Academic Press, 1989, v.42, p.43-83.

SORATTO, R.P.; LIMA, E.V.; MAUAD, M.; BOAS, R.L.V.; NAKAGAWA, J. Millet seeds mixed with phosphate fertilizers. Scientia Agricola, v.60, n.3, p.573579, 2003. http://www.scielo.br/scielo.php?script=sci arttext\&pid=S0103-90162003000300024
SILVA, J.B.C. Utilização de sementes peletizadas. Brasília, DF: EMBRAPA-CNPH, 1998. 2p. (EMBRAPACNPH. Comunicado Técnico da Embrapa Hortaliças, 10).

SILVA, J.B.C.; SANTOS, P.E.C.; NASCIMENTO, W.M. Desempenho de sementes peletizadas de alface em função do material cimentante e da temperatura de secagem dos péletes. Horticultura Brasileira, v.20, n.1, p.67-70, 2002.

SILVA, J.B.C.; NAKAGAWA, J. Metodologia para avaliação de materiais cimentantes para peletização de sementes. Horticultura Brasileira, v.16, n.1, p.3137, 1998a. http://www.scielo.br/scielo.php?script=sci arttext\&pid=S0102-0536200200010001

SILVA, J.B.C.; NAKAGAWA, J. Métodos para avaliação de materiais de enchimento utilizados na peletização de sementes. Horticultura Brasileira, v.16, n.1, p.44-49, 1998b. 